\title{
Floristic Composition, Structure and Regeneration Status of Riverine Forest at Nech Sar National Park of Ethiopia
}

\author{
Mulugeta Kebebew ${ }^{1^{*}}$ and Hewan Demissie ${ }^{2}$
}

\author{
${ }^{1}$ Dept. of Biology, Arba Minch University, Arba Minch (21), Ethiopia \\ ${ }^{2}$ School of Plant and Horticulture Science, College of Agriculture, Hawassa University, Hawassa (14 17), Ethiopia
}

\section{Corresponding Author}

Mulugeta Kebebew

e-mail: mulugetakebebew1@gmail.com

\author{
Article History \\ Manuscript No. AR1791 \\ Received in $20^{\text {th }}$ Jan, 2017 \\ Received in revised form $4^{\text {th }}$ Feb, 2017 \\ Accepted in final form $7^{\text {th }}$ Feb, 2017
}

\begin{abstract}
This Study was conducted in Nech Sar National park, Gamo Gofa Zone, Southern Ethiopia from February, 2011-March, 2012 for analyzing floristic composition, structure and regeneration status of woody plant species. The floristic composition and population structure of woody plant species were recorded in 76 quadrats, each of which $20 \times 20 \mathrm{~m}^{2}$ size. Data on species cover abundance, DBH, height and numbers of individuals per species and altitude were recorded from each quadrat. From NNP Riverine Forest 86 vascular plant species, representing 65 genera and 30 families were recorded. The family Fabaceae had the highest no. of species (11) followed by Euphorbiaceae each with 7 species, Sapindaceae and Tiliaceae each by 5 species. The four most abundant woody plant species in the forest were Lecaniodiscus fraxinifolus, Trichilia dregeana, Syzygium guineense, Euclea divinorum. Moreover, the five most frequently distributed woody plant species were Lecaniodiscus fraxinifolus, Trichilia dregeana, Syzygium guineense, Euclea divinorum and Maytenus senegalensis. Three communities: Lecaniodiscus fraxinifolius-Trichilia dregeana community, Trichilia dregeana-Syzygium guineense community and Syzygium guineenseLecaniodiscus fraxinifolius community were recognized, with similarity coefficients of 0.65 , indicating that there are moderate similarity among the communities. The Shannon-Wiener diversity and evenness in the forest were 2.92 and 0.68 respectively, indicating high diversity. The matured, sapling and seedling density of species were $1815.8(23.3 \%), 1344.1(17.2 \%)$ and $4635.9(59.5 \%)$ stems ha-1. The population structure in the forest revealed that there is a need of conservation for communities with poor regeneration status.
\end{abstract}

Keywords: Structure, diversity, species richness, regeneration, Nechsar riverine vegetation

\section{Introduction}

Ethiopia is known as the biodiversity hotspot and center of origin and diversification for a significant number of plants, animals and their wild relatives due to its dramatic geological history, broad latitudinal spread and immense altitudinal range. This variety led to the emergence of habitats that are suitable for the evolution and survival of various plants and animal species, which contributes to the overall biodiversity of the country (Tamene et al., 2011). The country flora has approximately $6000-7000$ species of higher plants, of which about $780-840$ (12-13\%) are endemic (Nune et al., 2007). However, the wildlife resources and their natural habitats in Ethiopia are facing various problems due to population pressure, poverty, inappropriate farming systems, climatic changes and other related problems (Samson et al., 2010).

Nech Sar National Park (NNP) is one of the protected areas in Ethiopia with diverse component of biological resources which are ecologically and economically important. However, the problems are more intensified and the wildlife population has gradually declined from time to time. Some of the major problems that contribute to the destruction of natural habitats, and hence wildlife in NNP were temporary and permanent settlement, charcoal making, firewood collection, overgrazing, deliberate fire to clear the vegetation for agriculture and selective tree cutting for construction were the main threats in the NNP (Samson et al., 2010; NNP, 2015). This factor is responsible for the decline in their habitat and population density (Workneh et al., 2016).

Arba Minch Natural forest was one of the forests of Nech Sar National Park victimized by these anthropogenic activities as well as environmental factors. Awareness and knowledge on sustainable use and management were very much less (Aramde et al., 2012). According to FAO (2007), the diversity, regeneration status, floristic composition, and vegetation structure are crucial elements to clearly visualize the anthropogenic activities as well as environmental factors affecting the vegetation of an area. Hence, for effective management and conservation of this unique ecosystem of the country, there is an urgent need to develop a sound management and conservation plan, and this, in turn, required 
detailed baseline information on the ecology and status of the area. Therefore, the objective of this paper is to present the results of the study of the vegetation Diversity and structure of Arba Minch Natural Forest and provide reliable information for the development of appropriate management plan for effective conservation of the park resources.

Thus the objectives of the present study are to: (i) compile floristic composition woody plant species, (ii) identify and describe the major plant-community types existing within the study area, (iii) make comparisons of species richness, evenness and diversity among different plant community types, (iv) analyze the species population-structure and regeneration status of the woody plant species of the study area and $(v)$ identify the forest disturbance of the study area.

\section{Materials and Methods}

\subsection{Study site}

The study was conducted at Nech Sar National Park (NNP), which is situated between $5^{\circ} 51^{\prime}-6^{\circ} 10^{\prime} \mathrm{N}$ and $37^{\circ} 32^{\prime}-37^{\circ} 48^{\prime}$ $E$ is located some $500 \mathrm{~km}$ away from the capital city Addis Ababa and $279 \mathrm{~km}$ south west of Hawassa, near the town of Arba Minch, in Gamo Gofa Zone, SNNPR, (Figure 1). The elevation of the land in park ranges from 1,108-1,650 MSL. Part of the park is located between Abaya and Chamo lakes (Awulachew, 2006), and extends to the west to the outskirts of Arba Minch town. It is one of the important National parks in Ethiopia, which supports varieties of wildlife (Chanie and Tesfaye, 2015). The park is bounded by the Amaro hills to the east, and Lake Abaya and Lake Chamo to north and south respectively. The area of the park is $514 \mathrm{~km}^{2}$, of which 436 $\mathrm{km}^{2}$ is land and $78 \mathrm{~km}^{2}$ is water body. The topography of the area is undulating with characteristic of low hills bordering much of the shores of the two lakes. There are two main river systems that flow through the park forming riverine forests and woodlands. Sermelle River crosses north to south at the eastern part of the park along the grassy plains. Kulfo River flows at the most western parts. In addition, the park also possesses forty springs and other hot spring. Its territory extends between $05^{\circ} 59^{\prime}-06^{\circ} 30^{\prime} \mathrm{N}$ latitude and $37^{\circ} 32^{\prime}-37^{\circ} 48^{\prime}$ E longitude with altitudinal ranges of $1108 \mathrm{~ms}$ lake Chamo and $1690 \mathrm{msl}$ at the peak of Geda hill.

The climate of the study area (NNP) is characterized by having

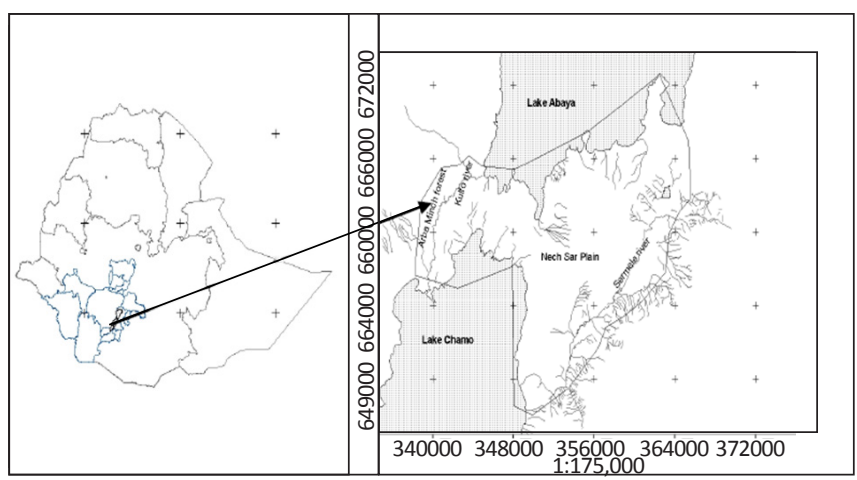

Figure 1: Map of the study area relatively hot climatic conditions with lower and unevenly distributed rainfall pattern with regularly higher temperature. According to data obtained from Arba Minch meteorological station the annual rainfall in the region is bimodal, with a long rain season during March-May, and a short rain season during September- November. The mean annual rainfall for the period 1987-2012 was $866.39 \mathrm{~mm}$. The mean annual maximum and minimum temperatures were $30.2^{\circ} \mathrm{C}$ and 17.4 ${ }^{\circ} \mathrm{C}$ respectively

\subsection{Data collection}

Data collection was made from February, 2011-March, 2012. Systematic sampling were used for the study. For each of the sampling sites, two transect lines (right and left side) of the main river of Kulfo were chosen. Sampling sites were arranged along Kulfo river in three (S, SE, SW) directions. The starting point of the right left side of Kulfo River for transect one and from near Lake Abaya down to the end Lake Chamo for transects two. The two transect lines each having 38 main plots were used to sample vegetation data, this resulted a total of 76 main sampling plots. The plots with equal size of $20 \times 20$ $\mathrm{m}^{2}\left(400 \mathrm{~m}^{2}\right)$ were laid out to collect the data on woody plant species at distance of $50 \mathrm{~m}$ between the two transect. In each sample plot type of species, presence or absence, count of saplings and seedlings, Diameter at Breast Height (DBH) and height measurements were made for all trees, shrubs and lianas (there are some shrubs and lianas which have no DBH). The vernacular (local) names were used when available. Dead and standing tree, stumps and logs in the quadrats were also recorded whenever encountered. Trees/shrubs are defined as woody plants with diameter at breast height $(\mathrm{DBH}) \geq 2.5$ $\mathrm{cm}$. In each of these quadrats, the numbers of all seedlings that are less than $1 \mathrm{~m}$ in height were recorded. The coverabundance value of each species was estimated based on 1-9 scale of Braun-Blanquet. Where, 1=rare generally only one individual; $2=$ sporadic (few) which are less than $5 \%$ cover of the total area; $3=$ abundant with less than $5 \%$ cover of the total area; $4=$ very abundant and less than $5 \%$ cover of the total area; $5=5-12 \%$ cover of the total area; $6=12.5-25 \%$ cover of the total area; $7=25-50 \%$ cover of the total area; $8=50-75 \%$ cover of the total area; $9=75-100 \%$ cover of the total area. The plants species were collected, pressed, dried and their names were determined by using the different volumes of Flora books of Ethiopia and Eritrea at the establishing herbarium of Arba Minch University and at the National Herbarium (ETH), Addis Ababa University.

\subsection{Data analysis}

All individuals of woody plant species recorded in all quadrants were used in the analysis of vegetation structure. Diameter is calculated from circumference. Basal area is measured by dividing the diameter at breast height $(\mathrm{m})$ by four expressed in square $\mathrm{m} \mathrm{ha}^{-1}$ and used to calculate the dominance of species. Density is calculated as the number of individual species per unit area and relative density is calculating number of individual's species by total number of all species. Furthermore the frequency of the vegetation 
is calculated by dividing the number of quadrant in which the species recorded by total number of quadrant. While relative frequency is measured as frequency of species divided by sum of frequencies of all species. And abundance is calculated as the number of individual species by number of plots in which the species occurred. Dominance and Important value index is measure by dividing abundance of species overabundance of all species while important value index is measured by adding relative density, relative dominance and relative frequency. Shannon-Wiener diversity index, Evenness and Jaccard similarity index analyzed in the R v. 3.2.2 environment. We used functions of its basic interface and package Vegan (Oksanen et al., 2016).

Indicator species values were calculated for each woody plant species to identify the species characterizing each community with package 'labdsv' (Roberts, 2015) in program R 3.2.2 (2015). The plant community types were named after two or three dominant species selected using the relative magnitude of their mean cover-abundance values. Hierarchical cluster analysis (classification) was made using $\mathrm{R}$ software version 3.2. We typically use the hclust function to perform hierarchical cluster analysis (Maechler et al., 2015). The analysis was based on the abundance of the species (number of individuals). The identified groups were tested for the hypothesis of no difference between the groups using the multi-purpose permutation procedure (Oksanen et al., 2016).

\section{Results and Discussion}

\subsection{Species composition}

A total of 75 woody species representing 64 genera and 30 families were recorded from the study area (Appendix 1). The floristic composition contributed by trees, shrubs and lianas was 55, 17 and 3 respectively (Figure 2). With regards to species no. Fabaceae (11 species), Euphorbiaceae (7 species),

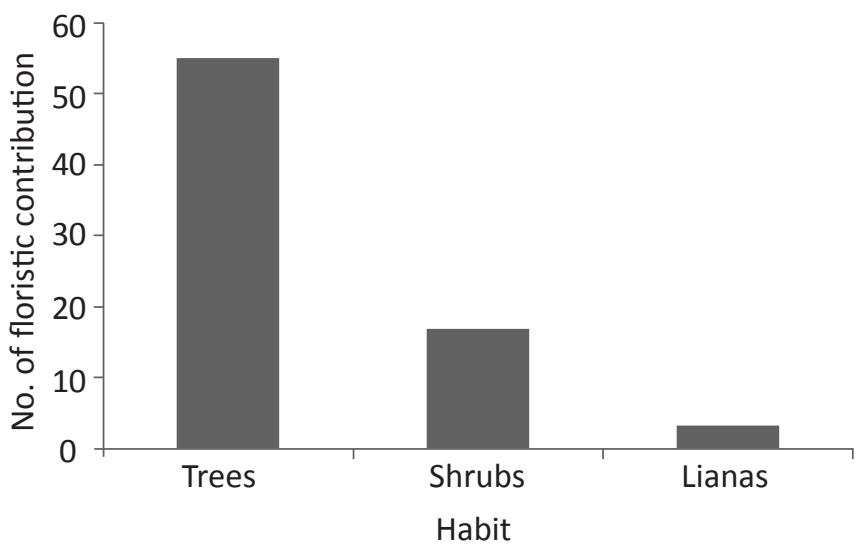

Figure 2: Habit of plant species in the forest

Appendix 1: Density ha $^{-1}$, Frequency, Dominance and IVI of species

\begin{tabular}{|c|c|c|c|c|c|c|c|c|c|c|c|c|}
\hline No. & Scientific name of species & Family & $\mathrm{HA}$ & $\mathrm{MA}$ & $\mathrm{D}$ & SA & $\mathrm{D}$ & $\mathrm{S}$ & $\mathrm{D}$ & Fre & DOM & IVI \\
\hline 1. & Acacia albida & Faba & $\mathrm{T}$ & 7 & 2.3 & 0 & 0 & 0 & 0 & 0.08 & 35.64 & 2.29 \\
\hline 2. & Acacia mellifera & Fabaceae & $\mathrm{T}$ & 3 & 0.99 & 0 & 0 & 0 & 0 & 0.03 & 5.88 & 0.52 \\
\hline 3. & Acacia polyacantha & Fabaceae & $\mathrm{T}$ & 27 & 8.89 & 1 & 0.33 & 8 & 2.63 & 0.12 & 41.49 & 3.22 \\
\hline 4. & Acacia tortilis & Fabaceae & $\mathrm{T}$ & 13 & 4.28 & 0 & 0 & 0 & 0 & 0.08 & 21.86 & 1.81 \\
\hline 5. & Acalypha fruticosa & Euphorbiaceae & $\mathrm{SH}$ & 28 & 9.21 & 3 & 0.99 & 2 & 0.66 & 0.21 & 0.1 & 2.19 \\
\hline 6. & Acalypha spp & Euphorbiaceae & $\mathrm{SH}$ & 74 & 24.34 & 3 & 0.99 & 19 & 6.25 & 0.42 & 0.21 & 4.7 \\
\hline 7. & Aeschynomene abyssinica & Fabaceae & $\mathrm{T}$ & 9 & 2.96 & 1 & 0.33 & 0 & 0 & 0.07 & 7.97 & 1.03 \\
\hline 8. & Allophylus rubifolius & Sapindaceae & $\mathrm{T}$ & 10 & 3.29 & 0 & 0 & 0 & 0 & 0.01 & 0.32 & 0.3 \\
\hline 9. & Anogeissus leiocarpa & Combretaceae & $\mathrm{T}$ & 1 & 0.33 & 0 & 0 & 3 & 0.99 & 0.01 & 1.79 & 0.2 \\
\hline 10. & Balanites aegyptiaca & Balantiaceae & $\mathrm{T}$ & 1 & 0.33 & 0 & 0 & 0 & 0 & 0.01 & 0.31 & 0.14 \\
\hline 11. & Bersama abyssinica & Melianthaceae & $\mathrm{T}$ & 11 & 3.62 & 1 & 0.33 & 2 & 0.66 & 0.09 & 10.21 & 1.37 \\
\hline 12. & Boswellia neglecta & Burseraceae & $\mathrm{T}$ & 3 & 0.99 & 0 & 0 & 0 & 0 & 0.03 & 0.79 & 0.3 \\
\hline 13. & Bridelia micrantha & Euphorbiaceae & $\mathrm{T}$ & 3 & & 0 & 0 & 0 & 0 & 0.03 & 0.47 & 0.28 \\
\hline 14. & Cadaba farinosa & Capparidaceae & $\mathrm{SH}$ & 9 & 2.96 & 0 & 0 & 0 & 0 & 0.05 & 0.04 & 0.72 \\
\hline 15. & Caesalpinia decaptala & Moraceae & $\mathrm{SH}$ & 23 & 7.57 & 1 & 0.33 & 5 & 1.64 & 0.16 & 0.06 & 1.68 \\
\hline 16. & Calpurnia aurea & Fabaceae & $\mathrm{SH}$ & 1 & 0.33 & 0 & 0 & 0 & 0 & 0.01 & 0.02 & 0.12 \\
\hline 17. & Canthium oligocarpum & Rubiaceae & $\mathrm{T}$ & 5 & 1.64 & 0 & 0 & 2 & 0.66 & 0.04 & 1.45 & 0.47 \\
\hline 18. & Capparis tomentosa & Capparidaceae & $\mathrm{SH}$ & 1 & 0.33 & 0 & 0 & 2 & 0.66 & 0.01 & 0.02 & 0.12 \\
\hline 19. & Carissa edulis & Apocynaceae & $\mathrm{SH}$ & 25 & 8.22 & 3 & 0.99 & 2 & 0.66 & 0.17 & 0.07 & 1.83 \\
\hline 20. & Celtis africana & Ulmaceae & $\mathrm{T}$ & 39 & 12.83 & 1 & 0.33 & 2 & 0.66 & 0.25 & 31.21 & 4.04 \\
\hline
\end{tabular}

HA: Habit; MA: Mature; D: Density; SA: Sapling; S: Seedling; Fre: Frequency; DOM: Dominance 


\begin{tabular}{|c|c|c|c|c|c|c|c|c|c|c|c|c|}
\hline No. & Scientific name of species & Family & $\mathrm{HA}$ & MA & D & SA & D & S & D & Fre & DOM & IVI \\
\hline 21. & Celtis zenkeri & Ulmaceae & $\mathrm{T}$ & 5 & 1.64 & 0 & 0 & 0 & 0 & 0.05 & 0.06 & 0.51 \\
\hline 22. & Citrus aurantifolia & Rutaceae & $\mathrm{T}$ & 2 & 0.66 & 1 & 0.33 & 0 & 0 & 0.03 & 0.02 & 0.25 \\
\hline 23. & Combretum molle & Combretaceae & $\mathrm{T}$ & 65 & 21.38 & 2 & 0.66 & 4 & 1.32 & 0.26 & 8.73 & 3.64 \\
\hline 24. & Commiphora albiflora & Burseraceae & $\mathrm{T}$ & 3 & 0.99 & 0 & 0 & 0 & 0 & 0.04 & 0.33 & 0.38 \\
\hline 25. & Cordia africana & Boraginaceae & $\mathrm{T}$ & 29 & 9.54 & 5 & 1.64 & 7 & 2.3 & 0.21 & 40.59 & 3.95 \\
\hline 26. & Cordia monoica & Boraginaceae & $\mathrm{T}$ & 40 & 13.16 & 2 & 0.66 & 10 & 3.29 & 0.26 & 8.01 & 3.16 \\
\hline 27. & Croton macrostachyus & Euphorbiaceae & $\mathrm{T}$ & 15 & 4.93 & 4 & 1.32 & 1 & 0.33 & 0.13 & 11.43 & 1.81 \\
\hline 28. & Diospyros abyssinica & Ebenaceae & $\mathrm{T}$ & 10 & 3.29 & 0 & 0 & 0 & 0 & 0.07 & 3.93 & 0.87 \\
\hline 29. & Dovyalis abyssinica & Flacourtiaceae & $\mathrm{T}$ & 6 & 1.97 & 0 & 0 & 0 & 0 & 0.05 & 5.02 & 0.74 \\
\hline 30. & Erythrococca trichogyne & Euphorbiaceae & $\mathrm{T}$ & 6 & 1.97 & 0 & 0 & 0 & 0 & 0.04 & 3.91 & 0.59 \\
\hline 31. & Euclea divinorum & Ebenaceae & $\mathrm{T}$ & 347 & 114.14 & 55 & 18.09 & 108 & 35.53 & 0.55 & 75.11 & 13.91 \\
\hline 32. & Ficus sycomorous & Moraceae & $\mathrm{T}$ & 110 & 36.18 & 26 & 8.55 & 20 & 6.58 & 0.58 & 1067.6 & 52.76 \\
\hline 33. & Ficus thonningii & Moraceae & $\mathrm{T}$ & 1 & 0.33 & 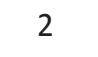 & 0.66 & 2 & 0.66 & 0.01 & 1.56 & 0.19 \\
\hline 34. & Flueggea virose & Euphorbiaceae & $\mathrm{T}$ & 2 & 0.66 & 0 & 0 & 1 & 0.33 & 0.03 & 7.08 & 0.55 \\
\hline 35. & Garcinia livingstonei & Rhizophoraceae & $T$ & 2 & 0.66 & 0 & 0 & 2 & 0.66 & 0.03 & 0.46 & 0.27 \\
\hline 36. & Grewia ferruginea & Tiliaceae & $\mathrm{SH}$ & 19 & 6.25 & 0 & 0 & 7 & 2.3 & 0.17 & 0.09 & 1.9 \\
\hline 37. & Grewia villosa & Tiliaceae & $\mathrm{SH}$ & 59 & 19.41 & 18 & 5.92 & 19 & 6.25 & 0.29 & 0.13 & 3.5 \\
\hline 38. & Harrisonia abyssiniaca & Burseraceae & $\mathrm{T}$ & 3 & 0.99 & 0 & 0 & 0 & 0 & 0.03 & 0.46 & 0.28 \\
\hline 39. & Hippocratea africana & Celastraceae & L & 6 & 1.97 & 0 & 0 & 0 & 0 & 0.05 & 0.06 & 0.53 \\
\hline 40. & Kigelia africana & Bignoniaceae & $\mathrm{T}$ & 8 & 2.63 & 1 & 0.33 & 0 & 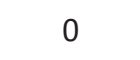 & 0.08 & 20.07 & 1.64 \\
\hline 41. & Lantana camara & Verbenaceae & $\mathrm{SH}$ & 76 & 25 & 16 & 5.26 & 33 & 10.86 & 0.33 & 0.09 & 4.04 \\
\hline 42. & Lecaniodiscus fraxinifolius & Sapindaceae & $\mathrm{T}$ & 1530 & 503.29 & 1381 & 454.28 & 4873 & 1602.96 & 0.99 & 235.93 & 45.7 \\
\hline 43. & Lepisanthes senegalensis & Sapindaceae & $\mathrm{T}$ & 35 & 11.51 & 8 & 2.63 & 28 & 9.21 & 0.28 & 28.44 & 4.06 \\
\hline 44. & Mangifera indica & Anacardiaceae & $\mathrm{T}$ & 2 & 0.66 & 0 & 0 & 2 & 0.66 & 0.03 & 0.12 & 0.25 \\
\hline 45. & Maytenus arbutifolia & Celastraceae & $\mathrm{T}$ & 5 & 1.64 & 0 & 0 & 2 & 0.66 & 0.04 & 0.04 & 0.41 \\
\hline 46. & Maytenus senegalensis & Celastraceae & $\mathrm{T}$ & 180 & 59.21 & 74 & 24.34 & 89 & 29.28 & 0.66 & 43.06 & 10.34 \\
\hline 47. & Oncoba spinosa & Flacortiaceae & $\mathrm{T}$ & 1 & 0.33 & 1 & 0.33 & 0 & 0 & 0.01 & 0.02 & 0.12 \\
\hline 48. & Pappea capensis & Sapindaceae & $\mathrm{T}$ & 6 & 1.97 & 2 & 0.66 & 2 & 0.66 & 0.04 & 3.13 & 0.56 \\
\hline 49. & Paullinia pinnata & Sapindaceae & $\mathrm{L}$ & 49 & 16.12 & 1 & 0.33 & 1 & 0.33 & 0.28 & 0.15 & 3.14 \\
\hline 50. & Phytolacca dodecandra & Phytolaccaceae & L & 4 & 1.32 & 0 & 0 & 0 & 0 & 0.05 & 0.12 & 0.49 \\
\hline 51. & Prunus africana & Rosaceae & $\mathrm{T}$ & 4 & 1.32 & 0 & 0 & 0 & 0 & 0.05 & 0.09 & 0.49 \\
\hline 52. & Pterolobium stellatum & Fabaceae & $\mathrm{SH}$ & 28 & 9.21 & 3 & 0.99 & 7 & 2.3 & 0.24 & 0.13 & 2.41 \\
\hline 53. & Rhus glutinosa & Anacardiaceae & $\mathrm{T}$ & 25 & 8.22 & 7 & 2.3 & 14 & 4.61 & 0.21 & 3.74 & 2.28 \\
\hline 54. & Rhus natalensis & Anacardiaceae & $\mathrm{T}$ & 10 & 3.29 & 0 & 0 & 0 & 0 & 0.08 & 3.24 & 0.95 \\
\hline 55. & Ricinus cummunis & Euphorbiaceae & $\mathrm{T}$ & 6 & 1.97 & 2 & 0.66 & 3 & 0.99 & 0.05 & 0.14 & 0.53 \\
\hline 56. & Rubus apetalus & Rosaceae & $\mathrm{SH}$ & 2 & 0.66 & 0 & 0 & 0 & 0 & 0.03 & 0.03 & 0.26 \\
\hline 57. & Senna bicapsularis & Fabaceae & $\mathrm{SH}$ & 14 & 4.61 & 12 & 3.95 & 77 & 25.33 & 0.11 & 0.1 & 1.1 \\
\hline 58. & Sesbania sesban & Fabaceae & $\mathrm{T}$ & 2 & 0.66 & 0 & 0 & 0 & 0 & 0.01 & 0.03 & 0.14 \\
\hline 59. & Solanum incanum & Solanaceae & $\mathrm{SH}$ & 5 & 1.64 & 0 & 0 & 0 & 0 & 0.03 & 0.05 & 0.3 \\
\hline 60. & $\begin{array}{l}\text { Stereospermum kunthia- } \\
\text { num }\end{array}$ & Bignoniaceae & $\mathrm{T}$ & 10 & 3.29 & 0 & 0 & 0 & 0 & 0.07 & 4 & 0.88 \\
\hline
\end{tabular}




\begin{tabular}{|c|c|c|c|c|c|c|c|c|c|c|c|c|}
\hline No. & Scientificname of species & Family & $\mathrm{HA}$ & MA & D & SA & D & $S$ & D & Fre & DOM & IVI \\
\hline 61. & Syzygium guineense & Myrtaceae & $\mathrm{T}$ & 870 & 286.18 & 754 & 248.03 & 1721 & 566.12 & 1.00 & 169.46 & 31 \\
\hline 64. & Tamarindus indica & Fabaceae & $\mathrm{T}$ & 25 & 8.22 & 4 & 1.316 & 9 & 2.96 & 0.20 & 30.06 & 3.32 \\
\hline 62. & Teclea nobilis & Rutaceae & $\mathrm{T}$ & 175 & 57.57 & 100 & 32.89 & 161 & 52.96 & 0.61 & 3.47 & 8.12 \\
\hline 63. & Terminalia brownii & Combretaceae & $\mathrm{T}$ & 10 & 3.29 & 6 & 1.97 & 11 & 3.62 & 0.07 & 8.77 & 1.08 \\
\hline 65. & Trema orientalis & Ulmaceae & $\mathrm{T}$ & 17 & 5.59 & 0 & 0 & 0 & 0 & 0.08 & 6.1 & 1.2 \\
\hline 66. & Trichilia dregeana & Meliaceae & $\mathrm{T}$ & 1138 & 374.34 & 1401 & 460.86 & 6610 & 2174.34 & 0.96 & 240.05 & 38.58 \\
\hline 67. & Trichilia emetica & Meliaceae & $\mathrm{T}$ & 89 & 29.28 & 19 & 6.25 & 39 & 12.83 & 0.41 & 78.11 & 8.22 \\
\hline 68. & Triumfetta rhomboidea & Tiliaceae & $\mathrm{SH}$ & 3 & 0.99 & 0 & 0 & 7 & 2.3 & 0.04 & 0.08 & 0.37 \\
\hline 69. & Triumfetta tomentosa & Tiliaceae & $\mathrm{SH}$ & 2 & 0.66 & 0 & 0 & 1 & 0.33 & 0.03 & 0.05 & 0.25 \\
\hline 70. & Vepris dainellii & Rutaceae & $\mathrm{T}$ & 147 & 48.36 & 163 & 53.62 & 164 & 53.95 & 0.61 & 14.84 & 8.1 \\
\hline 71. & Vepris eugeniifolia & Rutaceae & $\mathrm{T}$ & 2 & 0.66 & 0 & 0 & 2 & 0.66 & 0.01 & 0.62 & 0.17 \\
\hline 72. & Vernonia amygdalina & Asteraceae & $\mathrm{T}$ & 7 & 2.3 & 0 & 0 & 0 & 0 & 0.05 & 1.82 & 0.62 \\
\hline 73. & Vernonia auriculifera & Asteraceae & $\mathrm{SH}$ & 1 & 0.33 & 0 & 0 & 0 & 0 & 0.01 & 0.03 & 0.12 \\
\hline 74. & Ximenia americana & Olaceae & $\mathrm{T}$ & 11 & 3.62 & 2 & 0.66 & 7 & 2.3 & 0.09 & 2.36 & 1.03 \\
\hline \multirow[t]{2}{*}{75.} & Ziziphus spina-cristi & Rhamaraceae & $\mathrm{T}$ & 8 & 2.63 & 0 & 0 & 2 & 0.66 & 0.04 & 4.19 & 0.64 \\
\hline & & & & 5520 & 1815.79 & 4086 & 1344.08 & 14093 & 4635.86 & & & \\
\hline
\end{tabular}

Sapindaceae and Tiliaceae ( 5 species each) were found to be the most species rich families but some of the families like Balantiaceae, Melianthaceae, Olaceae, Phytolaccaceae, Rhamaraceae, Rhizophoraceae, Rubiaceae, Solanaceae and Verbenaceae were found to be the least species rich families (1 species each). This dominance of Poaceae was reported from similar vegetation study of (Teshome et al., 2004; Anteneh et al., 2011; Negusse, 2006; Getachew et al., 2008). Whereas, the studies (Getaneh, 2006; Mekbib, 2012) showed the dominance of Poaceae. This may imply that the variation of different places in their ecological settings attributed to the variation of the dominating families.

\subsection{Plant community types}

Statistical analyses on the species level reveal a conspicuous floristical division of the investigated study sites into three communities (Figure 3 ). The similarity values in species composition between the communities ranged from 0.46 to 0.65 . More similarity coefficient $(S j=0.65$ ) was found between community $\mathrm{II}$ and $\mathrm{III}$ and less similarity $(\mathrm{Sj}=0.46)$ was between community I and III; this could be associated to slope, aspect, the anthropogenic and other environmental factors such as soil type and properties which were not considered in this study.

Community I contains the plot area from transect 1 by the side of Sermelle River which are characterized by the indicator species Trichilia dregeana $(p<0.001)$, Lecaniodiscus fraxinifolius $(p<0.001)$, while community II contains the plot are from transect 2 by the side of Kuflo River which are characterized by the indicator species Syzygium guineense $(p<0.05)$. As woody species diversity analysis revealed, Shannon-Wiener diversity index $\left(\mathrm{H}^{\prime}\right)$ of the study area is 2.92 and evenness ( $\mathrm{J}$ ) is 0.68 . This result indicates that the diversity and evenness of woody species in the forest is relatively high. The computation of Shannon-Wiener Diversity index revealed that Community type II and Community III had the highest species diversity but Community I was with the least species diversity of all communities (Table 1). In this community disturbance by logging, timber production,

Table 1: Comparison of plant species diversity $\left(\mathrm{H}^{\prime}\right)$, evenness (J) and richness (S) among the three community types following Shannon-Weiner index

\begin{tabular}{llll}
\hline Community & Richness & Diversity & Evenness \\
\hline I & 40 & 2.3 & 0.25 \\
II & 62 & 3.1 & 0.47 \\
III & 51 & 3.0 & 0.31 \\
\hline
\end{tabular}

charcoal production and road construction was observed. Comparatively Community II had the highest species richness. The possible reason for high species richness of community II may be mid altitude range. Because intermediate altitude could be associated with optimal conditions of environmental factors that favor vegetation growth and has even distribution of species indicating that the vegetation is expected to be natural with less human intervention; while community I revealed the least species richness (Figure 4) which could be attributed to anthropogenic activities such as logging, timber production, charcoal production and road construction and selective tree cutting. Significant effects of grazing, logging, timber production, charcoal production and road contraction pressure on species composition were also reported.

\subsection{Frequency distribution of Nechsar riverine forest}

The most frequent woody species in the study area was 


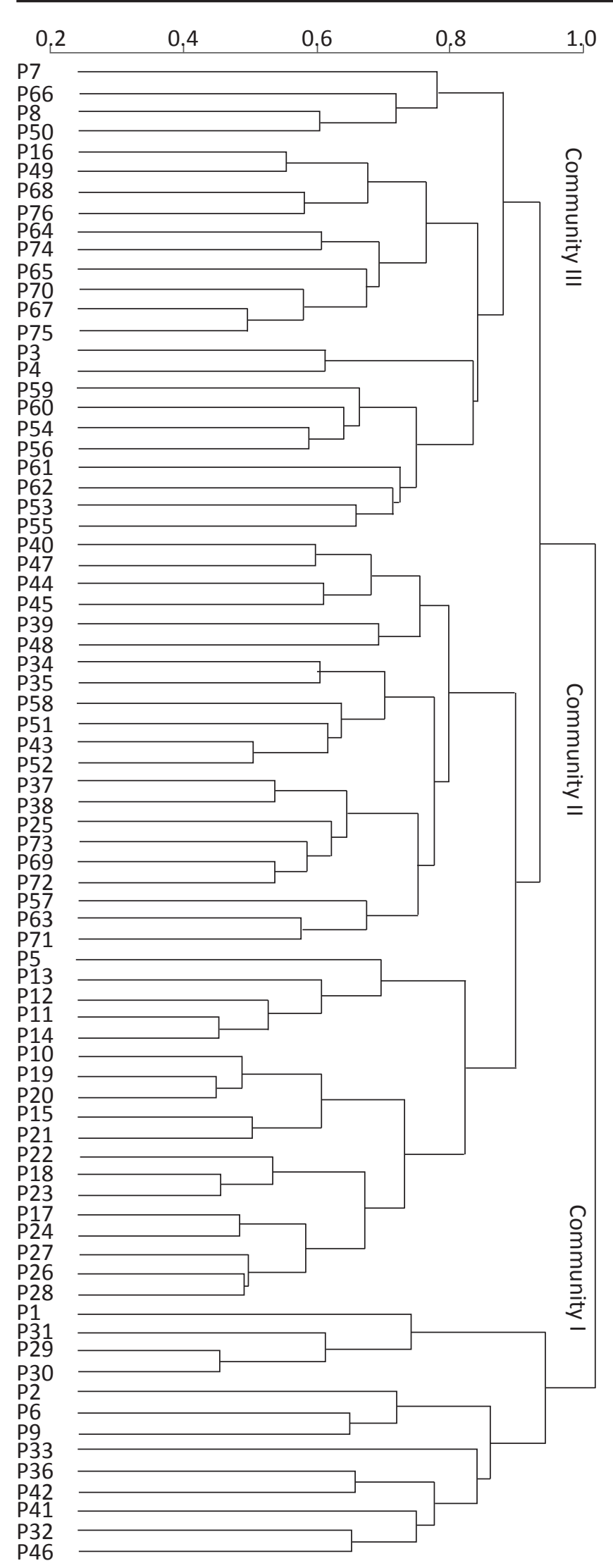

Figure 3: Denderogram that represent plant community types of Nech Sar National Park riverine forest

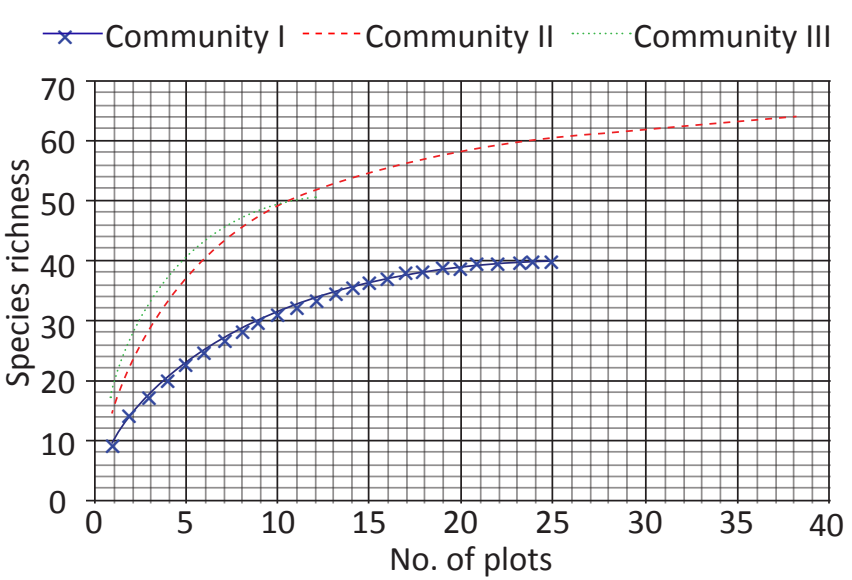

Figure 4: Species richness comparison among three plant community types

Syzygium guineense ssp. afromontanum (1.00), Lecaniodiscus fraxinifolius (0.99), Trichilia dregeana (0.96) and Maytenus arbutifolia (0.66) but the least frequent species were Balanitesaegyptiaca, Ficus thonningii, Vepris eugeniifolia, Anogeissus leiocarpa, Sesbania sesban, Allophylus rubifolius and Oncoba spinosa (0.01 each) due to anthropogenic factors. As reported by Dereje (2007), the higher the occurrence of a species the more imperative the plant is in the community. That is, a high frequency value is indication of the wide spread of the species in the study area. Conversely, high percentage of number of species in the low frequency classes and low percentage of number of species in the high frequency classes points out a high degree of floristic heterogeneity (Simon and Girma, 2004). The present study revealed a progressive decrease in the percentage number of species from the lower to a high frequency classes (Table 2). The result in the frequency class distribution of Nechisar National Park Riverine Forest confirms the existence of high degree of floristic heterogeneity.

Table 2: Species frequency class of Nechisar National Park Riverine forest

\begin{tabular}{lccc}
\hline & $\begin{array}{c}\text { Frequency } \\
\text { class }\end{array}$ & $\begin{array}{c}\text { Species } \\
\text { frequency }\end{array}$ & $\%$ \\
\hline A & $<10$ & 47 & 62.67 \\
B & $10.1-20$ & 7 & 9.33 \\
C & $20.1-30$ & 10 & 13.33 \\
D & $>30.1$ & 11 & 14.67 \\
Total & & 75 & 100 \\
\hline
\end{tabular}

\subsection{Vegetation density}

The overall density of woody species of the study vegetation whose $\mathrm{DBH}>2.5 \mathrm{~cm}$ was $\left(1815.79 \mathrm{ha}^{-1}\right)$ much greater than the Beschillo and Abay (Blue Nile) riverine vegetation (115 ha-1). Lecaniodiscus fraxinifolius $503.3 \mathrm{ha}^{-1}$, Trichilia dregeana; 374.4 $\mathrm{ha}^{-1}$, Syzygium guineense ssp. afromontanum; $286.2 \mathrm{ha}^{-1}$ and Euclea divinorum; 114.1 ha $^{-1}$ were woody species which have 
higher density in the study area. But Anogeissus leiocarpa, Balanites aegyptiaca, Calpurnia aurea, Capparis tomentosa, Ficus thonningii, Oncoba spinosa and Vernonia auriculifera have the least density of individuals ha ${ }^{-1}$ (0.33 each). On the other hand, the highest density $\left(949.7 \mathrm{ha}^{-1}\right)$ of woody plant species was observed for DBH class $2.5-10.0 \mathrm{~cm}$ and the lowest density $\left(351.6 \mathrm{ha}^{-1}\right)$ of woody species were observed in DBH class $10.1-20.0 \mathrm{~cm}$ which was considered as trees or shrubs. The density of plant species with DBH class as their contribution of the percentage numbers of species were given in Table 3. The present study revealed a progressive decrease in the percentage number of species from the lower to a high DBH classes. So the general pattern of DBH

\begin{tabular}{lcc}
\hline \multicolumn{3}{l}{ Table 3: No. of tree individuals under different DBH classes } \\
\hline DBH $(\mathrm{cm})$ & No. of individuals ha & (1) \\
\hline $2.5-10.0$ & 949.7 & 56.6 \\
$10.1-20.0$ & 351.6 & 21 \\
$>20.0$ & 375.7 & 22.4 \\
Total & 1677 & 100 \\
\hline
\end{tabular}

class size distribution forms an irregular inverted J-shape (Figure 5) for the most selected dominant trees species. This might be associated with selective cutting of trees by people for construction and other house use. Similar results were observed by Abate et al. (2006); Feyera and Demel (2001) and Fekadu et al. (2012).

\subsection{Tree height}

The trees in study area were divided into three arbitrary height classes: 1) $\leq 5 \mathrm{~m}, 2)$ 5-10 m, 3) $\geq 15 \mathrm{~m}$. Nech Sar National Park Riverine forest has high proportion (53.44\%) of individuals in the low height classes (i.e. $2.5-5 \mathrm{~m}$ ) but low proportion $(13.47 \%)$ of individual in the high height classes $(\geq 15 \mathrm{~m})$. The distribution of trees in different height classes is shown in (Figure 6).The percentage of tree decrease with increase in height class (that is the highest percentage of tree was found in the height class 1 , but, the least percentage of trees was found in height class 3 ). In other words, the numbers of individuals in height class decrease with increase in height range. The general height class distribution pattern indicates a normal distribution of species and maximum values occurred in the first class and reduced gradually up to the third class showing an inverted J-shape (Figure 6). As reported by Dikaso and Tesema (2016), higher number of small sized in the lowest height class in the natural forest implies the presence of good reproduction status and regeneration potential. The relationship of tree density and height class is opposite, where more density of each height class towards the lowest height classes reveals the dominance of small sized individuals in the forest which was the attribute of high rate of regeneration but poor recruitment.

\subsection{Vertical structure of the forest}

The vertical stratification of the tree in the study area was

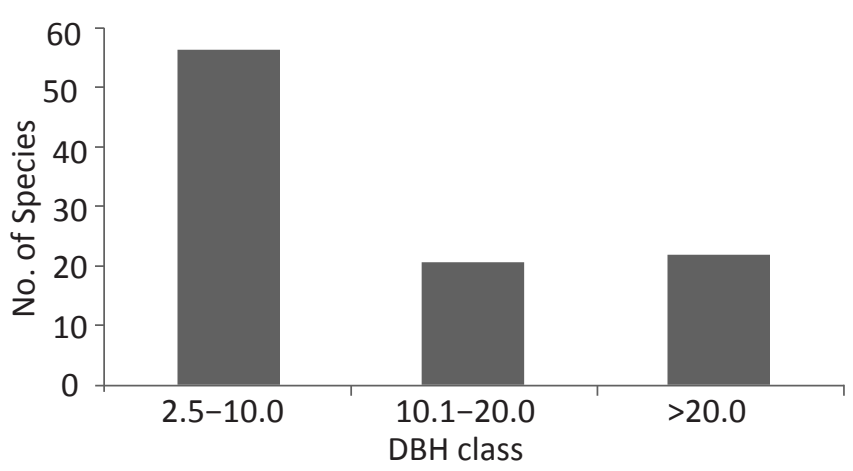

Figure 5: Percentage No. of tree individuals under different DBH classes

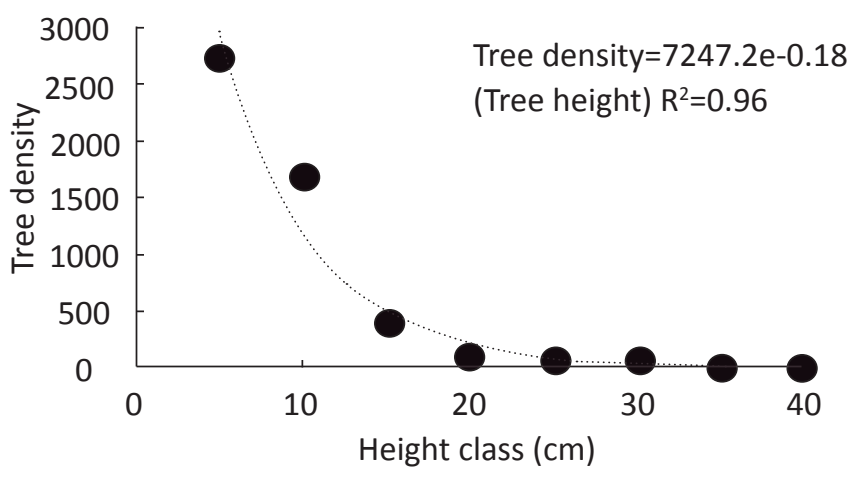

Figure 6: Height class distribution of tree species in Nechisar National Park Riverine Forest

examined using IUFRO classification scheme (Lamprecht, 1989). According to this scheme, tree with height above $2 / 3 \mathrm{~m}$ top height represent upper story, tree with height between $1 / 3$ and $2 / 3$ represent middle story and tree with height $<1 / 3$ represent lower story. Therefore, vertical stratification of the tree in the study area represent mainly lower story which is $72 \%$ of the individuals followed by the middle $(37.36 \%)$ and upper (6.7\%) of the vertical structure of the Nechisar National Park Riverine Forest (Table 4). This type of distribution might be explained by the fact that species with overlapping size distributions can coexist as a result of differences in maximum attainable size. And the presence of difference in tree height is

Table 4: Density and species number in the lower, middle and upper strata of NNP Riverine Forest

\begin{tabular}{lcccc}
\hline Stratum & No. of stem ha & \% & No. of species & $\%$ \\
\hline Lower & 1586.2 & 94.6 & 57 & 72 \\
Middle & 82.22 & 4.96 & 28 & 37.36 \\
Upper & 8.6 & 0.56 & 5 & 6.7 \\
\hline
\end{tabular}

one of the adaptive morphological basis for their demographic differentiation. This suggests that short species are likely to allocate more to radial growth, thereby acquiring the physical stability needed to survive in the riparian ecosystem.

\subsection{Basal area}

Total basal area of all tree species distributions from Nech Sar 
National Park riverine forest was found to be $46.04 \mathrm{~m} \mathrm{ha}{ }^{1}$. The basal area of the study area is greater than the basal area of Wotagisho forest ( $\left.45.14 \mathrm{~m} \mathrm{ha}^{1}\right)$. The highest basal area value of the forest was contributed by Euclea divinorum (21.08\%). Other large trees in this forest include Acacia albida which contributed (11.06\%), Ficus thonningii (7.68\%) and Harisonia abyssiniaca (5.45\%). Basal area provides a better measure of the relative importance of the species than simple stem count. Therefore, species with the largest contribution in basal area can be considered as the most important woody species in the forest. Species with higher basal area ha-1 does not always have higher density, indicating size differences between the species (Tamrat, 1994; Simon and Girma, 2004). Flueggea virose and Acacia mellifera possesses low density but high BA due to its maximum average DBH value. Therefore, contribution of these trees to the basal area is more than their contribution to the density of the forest.

Comparison of the basal areas and density in diameter classes (Figure 7, DBH and $\mathrm{BA}$ ) indicated that there were more individuals $(45.7 \%)$ in the first two diameter classes. But their contribution to the basal area is less than the ones in higher DBH classes. Many individuals in the lowest DBH classes are of a small stature (Tamrat, 1994). The basal area contribution by the lowest and the highest DBH classes is

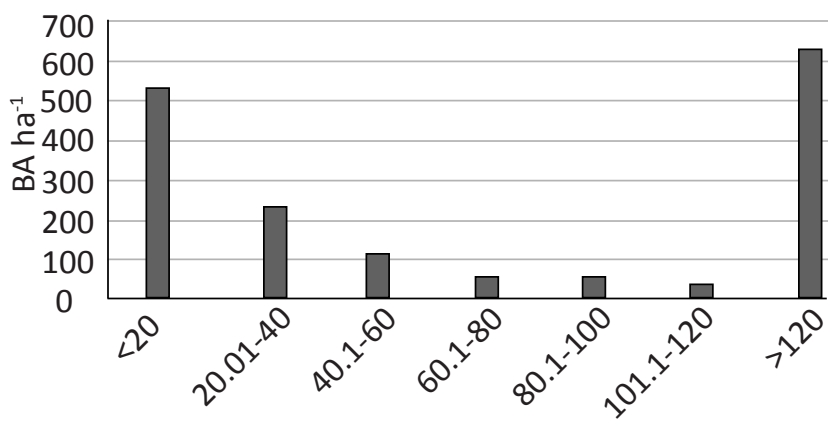

DBH class

Figure 7: Distribution of BA by diameter classes

very low as compared to the contribution of the intermediate classes. Compared to the $6^{\text {th }}$ and $7^{\text {th }}$ DBH classes, the $3^{\text {rd }}$ and $4^{\text {th }}$ diameter class $(40.01-60$ and $60.01-80 \mathrm{~cm}$ ) has relatively low contribution to the basal area due to less number of individuals which resulted from selective cutting of some species such as Cordiaafricana, Teclea nobilis, Vepris dainellii, Syzygium guineense spp. afromontum, Trichilia emetica and Euclea divinorum. The last diameter class $(>120 \mathrm{~cm})$ comprising fewer individuals contributed the most to the $\mathrm{BA}$. The trees belonging to higher $\mathrm{DBH}$ classes are fewer but contribute higher to the total basal area.

\subsection{Dominant plant species}

Out of 76 total plant species, the most relatively dominant species in Nech Sar National Park riverine forest was Ficus sycomorous which contributed $46.5 \%$ followed by Lecaniodiscus fraxinifolius which contributed $10.5 \%$ and Trichilia dregeana which contributed $10.3 \%$ (Table 5). But the least dominant species was Sesbania sesban which contributed $0.0013 \%$ followed by Oncoba spinosa and Citrus aurantifolia which contributed $0.00087 \%$ the total species.

\begin{tabular}{|c|c|c|c|}
\hline No. & Species & Dominance & $\%$ \\
\hline 1. & Ficus sycomorous & 1067.6 & 46.5 \\
\hline 2. & Lecaniodiscus fraxinifolius & 240.1 & 10.5 \\
\hline 3. & Trichilia dregeana & 235.9 & 10.3 \\
\hline 4. & $\begin{array}{l}\text { Syzygium guineense ssp. } \\
\text { afromontanum }\end{array}$ & 169.5 & 7.3 \\
\hline 5. & Euclea divinorum & 78.1 & 3.4 \\
\hline 6. & Maytenus arbutifolia & 75.1 & 3.3 \\
\hline 7. & Trichilia emetica & 43.1 & 1.9 \\
\hline
\end{tabular}

\subsection{Important index value (IVI)}

The highest IVI value was contributed by Ficus sycomorous (52.76), Lecaniodiscus fraxinifolius (45.7), Trichilia dregeana (38.58) and Syzygium guineense (31) (Table 6) and the lowest IVI value by Calpurnia aurea, Capparis tomentosa, Oncoba spinosa and Vernonia auriculifera (0.12 each). As indicated

Table 6: Importance value index (IVI) of the top 6 species of NNP Riverine forest

\begin{tabular}{llcccc}
\hline No. & Species & $\mathrm{RD}$ & $\mathrm{RF}$ & $\mathrm{RDo}$ & $\mathrm{IVI}$ \\
\hline 1. & Ficus sycomorous & 2.0 & 4.6 & 46.2 & 52.8 \\
2 & Lecaniodiscus fraxinifolius & 27.7 & 7.8 & 10.2 & 45.7 \\
3. & Trichilia dregeana & 20.6 & 7.6 & 10.4 & 38.6 \\
4. & $\begin{array}{l}\text { Syzygium guineense ssp. } \\
\text { afromontanum }\end{array}$ & 15.7 & 7.9 & 7.3 & 31.0 \\
5. & Euclea divinorum & 6.3 & 4.4 & 3.3 & 13.9 \\
6. & Maytenus arbutifolia & 3.3 & 5.2 & 1.9 & 10.3 \\
\hline
\end{tabular}

in IUFRO classification scheme (Lamprecht, 1989), IVI value is used for comparison of ecological significant of species in which high IVI values indicate that the species structure in the community is high.

\subsection{Population structure}

The species population structure analysis revealed, there are six tree population structures. The first pattern was bellshaped distribution formed by species with high number of individuals in the middle DBH classes (Figure 8a). In this pattern, the lowest DBH classes have lower densities followed by increase in the number of individuals towards the medium classes, and then a progressive decrease towards the high DBH classes. Species such as Acacia polyacantha and Acacia tortilis are characterized by this distribution pattern. This pattern indicates a poor reproduction and recruitment of species which may be associated with intense competition from the surrounding trees or may be associated with the 
overall harvesting of seed bearing individuals or the presence of only some seed bearing individuals. The second pattern was Trichilia emetica which shows inverted J-shaped diameter class of distribution (Figure 8b). These species had the highest density in the lower $\mathrm{DBH}$ with gradual decrease in density towards the bigger sizes, which suggested good reproduction and healthy regeneration potential in the forest. Species apparent with this pattern of population structure were Lecaniodiscus fraxinifolius, Lepisanthes senegalensis, Celtis africana, Combretum molle, Cordia africana, Euclea divinorum and Syzygium guineense ssp. afromontanum had inverted J-curve structure. In the same pattern, the representative species showed high density in the lower DBH classes and their density decrease substantially or absent in the higher $\mathrm{DBH}$ classes. The overall population structure pattern of a given species is an indication of healthy regeneration of the species and the forest. The third pattern is represented by Diospyros abyssinica, which shows a J-shaped pattern of distribution (Figure 8c). The J-shaped pattern reveals poor reproduction and in a week position of regeneration. In this pattern $\mathrm{DBH}$ classes was missed from one lower class and three or more higher DBH classes. Some species of this pattern have big individuals that are less competent to reproduce and hence show poor reproduction. Grazing which affects the seedlings under the mother tree could be another reason. Species included to this group are Acacia mellifera, Dovyalis abyssinica and Ficus thonningii. The fourth population structure shows an irregular pattern. Kigelia africana exhibited this type of distribution pattern (Figure 8d). In such pattern, the density of some individuals in the group decrease with increase $\mathrm{DBH}$ up to some points and then increases with increasing $D B H$. The pattern to decrease with increasing $\mathrm{DBH}$ and finally $\mathrm{DBH}$ classes was missed. This irregularity arises due to human intervention. The fifth pattern was represented by Ficus sycomorous with irregular or zigzag types of distribution (Figure 8e). In such pattern, the density of all individuals in the group decrease with increase $\mathrm{DBH}$ up to some points and then increases with increasing $\mathrm{DBH}$. The pattern continues to decrease with increasing $\mathrm{DBH}$ and finally ends with increasing density as $\mathrm{DBH}$ increases. The sixth pattern consists those species that occur only in the first and second DBH classes, but absent in the rest DBH classes (Figure $8 \mathrm{f}$ ). This pattern was represented by Cordia monoica, Rhus glutinosa, Rhus natalensis, Teclia nobilis and Vepris danielii. This may be due to selective cutting of the tree in the middle and higher DBH classes for construction.

\subsection{Regeneration status}

As regeneration density analysis revealed, the total seedling, sapling and mature woody plant species densities of 75 woody plant species were about 4636, 1344 and 1816 individuals per hectare respectively (Figure 9). The result shows the presence of more seedling than sapling and mature individuals. The study of Chauhan et al., (2008) show that calculation of the ratio among the mature tree, sapling and seedling can provide information regarding the distribution of mature tree, sapling and seedling and the regeneration status of the forest. In line with Chauhan et al. (2008) the ration of seedling to sapling, seedling to mature tree and sapling to mature tree of Nech Sar National Park riverine forest was conducted and the result was 169:49, 120:47 and 57:77 respectively. These reveal that the distribution of seedling density is greater than both sapling and mature tree (i.e. density of seedling>density of sapling<density of mature tree) within study area. According to Dhaulkhadi et al. (2008), a given forest had good regeneration if seedling is greater than sapling and mature tree/adult (seedling density>sapling density>mature tree/
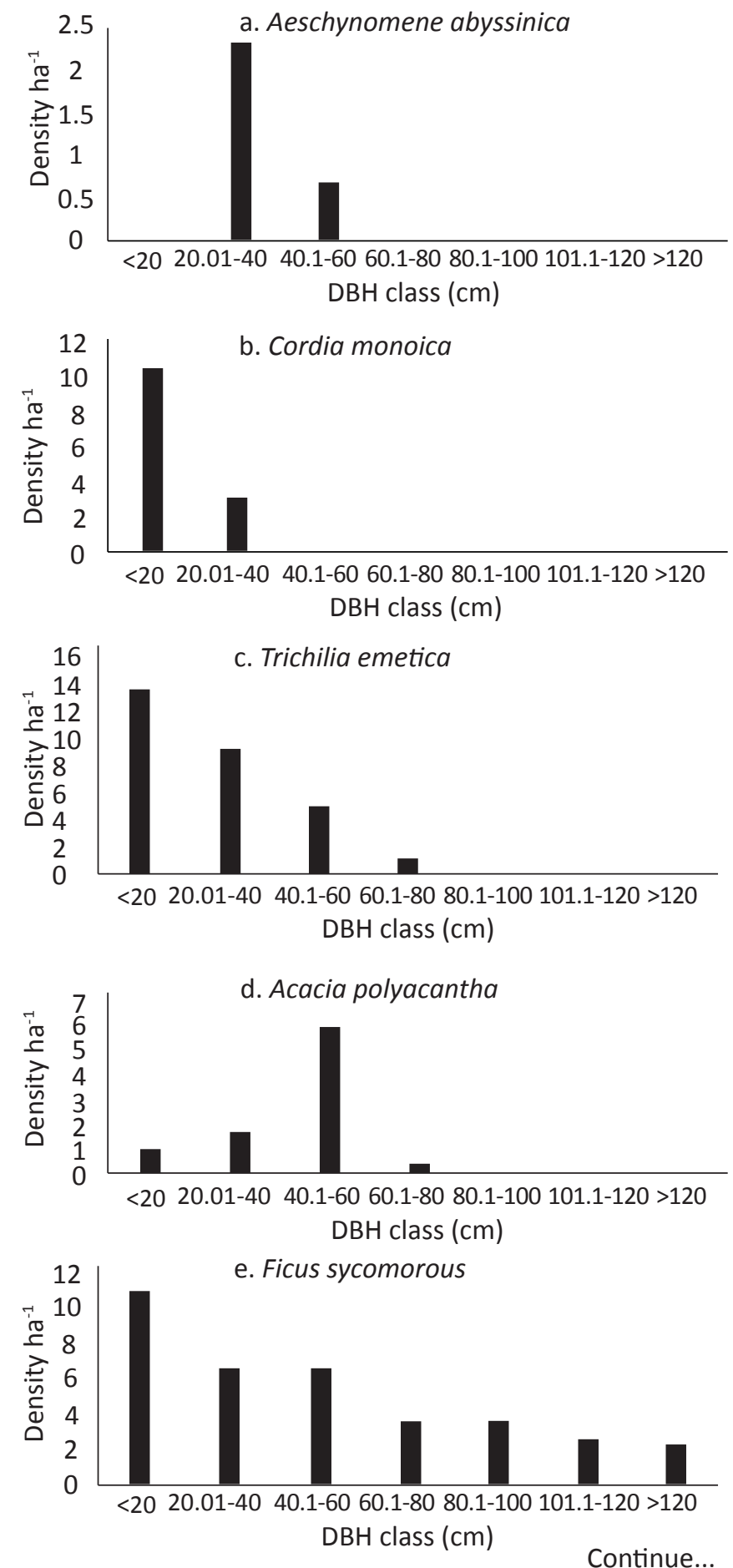


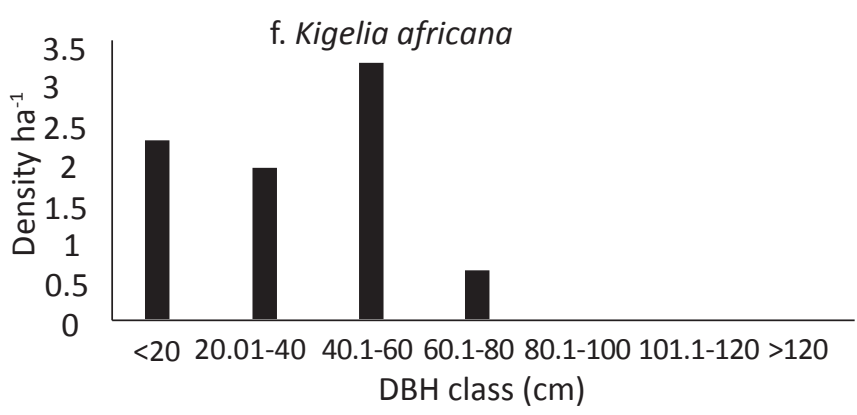

Figure 8: Tree Species Population Structure of Nech Sar National Park riverine forest

Density proportion (\%)

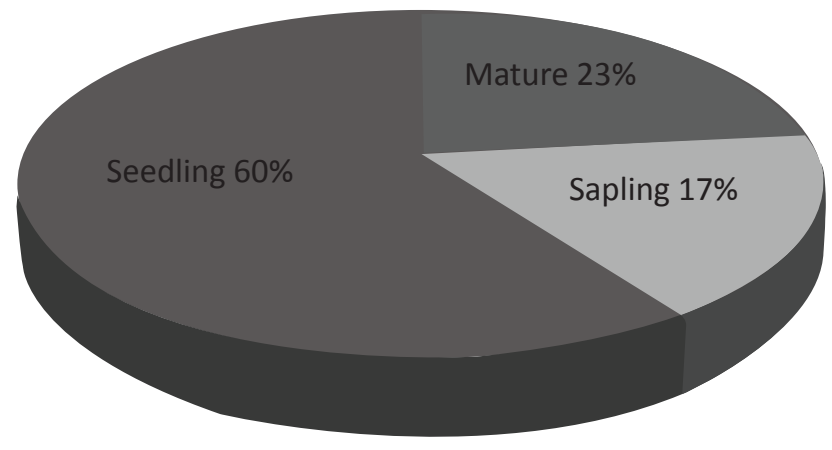

Figure 9: Seedling, sapling and mature woody species distribution in NNP riverine forest

adults); fair regeneration if seedling $>$ or $\leq$ sapling $\leq$ mature tree; poor regeneration if seedling<sapling $\geq 0 r \leq$ mature tree; and no regeneration if species are represented only by adult/mature trees. From the three conditions, the Nech Sar National Park riverine forest within study area fulfills the first condition and in general, it had good regeneration status. On the other hand, Based on these results of this study, woody plant species are grouped into 3 priority classes for conservation. These are class 1: those species with no seedling and sapling (Acacia albida, Acacia mellifera, Acacia tortilis, Allophylus rubifolius, Balanites aegyptiaca, Boswellia neglecta, Bridelia micrantha, Celtis zenkeri, Commiphora albiflora, Diospyros abyssinica, Dovyalis abyssinica, Erythrococca trichogyne, Harisonia abyssiniaca, Prunus africana, Rhus natalensis, Sesbania sesban, Stereospermum kunthianum, Trema orientalis and Vernonia amygdalina). This implies conservation activity should first focus on the species under Priority Class I and treats them as the first priority species to be conserved since they lack both seedlings and saplings. According to Lemenih and Teketay (2006), adverse conditions such as interventions by human being, poor seed bank, deterioration of seeds, disturbance by browsers, and grazers were the factors contributing for poor regeneration. This implies a need to develop and implement effective forest management system within the Priority I to promote healthy regeneration and sustainable use of these plant species. Class 2: those with seedlings but no sapling (Aeschynomene abyssinica, Citrus aurantifolia, Kigelia africana, Oncoba spinosa, Canthium oligocarpum, Flueggea virose, Garcinia livingstonei, Mangifera indica, Maytenus senegalensis, Anogeissus leiocarpa, Vepris eugeniifolia and Ziziphus spina-cristi). Class 3: those with both seedlings and saplings $>1$ individual ha-1 ${ }^{-1}$ (Acacia polyacantha, Bersama abyssinica, Celtis africana, Combretum molle, Euclea divinorum, Lecaniodiscus fraxinifolius, Maytenus arbutifolia, Syzygium guineense, Teclea nobilis, Trichilia dregeana, Vepris dainellii, Ximenia americana, Trichilia emetica, Tamarindus indica, Terminalia brownii, Ricinus cummunis, Rhus glutinosa, Pappea capensis, Lepisanthes senegalensis, Ficus thonningii, Ficus sycomorous, Croton macrostachyus, Cordia monoica and Cordia africana). The regeneration of the forest is affected not only by environmental factors but also by anthropogenic activities. Some of the anthropogenic activities seriously observed during data collection were cutting of trees for charcoal production, constructing wood, fence, and mowing grasses for fodder and covering roof of house which are related with observation by Deribe (2006); Markos and Simon (2015).

\section{Conclusion}

From this research 75 species identified. The populations are composed of trees (55), shrubs (17) and lianas (3). Fabaceae was dominant followed by Euphorbiaceae. Total density of the species per hectare $\left(1815.79 / \mathrm{ha}^{-1}\right)$ shows dense vegetation. High value of richness, diversity and evenness exhibited by the stream corridors of Kulfo River. The vegetation fall into three communities with varying degree of richness, diversity and evenness. The presence of species without seedling and sapling indicates threat mainly by anthropogenic activity.

\section{Acknowledgement}

We acknowledge Addis Ababa University, the National Herbarium of Ethiopia for their contribution during the study.

\section{References}

Abate, A., Tamrat, B., Sebsebe, D., 2006. The undifferentiated afromontane forest of Denkoro in the central highland of Ethiopia: Afloristic Structural analysis. Ethiopian Journal of Science and Technology 29, 45-56.

Anteneh, B., Tamrat, B., Sebsebe, D., 2011. The natural vegetation of Babile Elephant Sanctuary, Eastern Ethiopia: Implications for biodiversity conservation. Ethiopian Journal of Biological Sciences 10(2) 137-152.

Aramed, F., Bekele, T., Tiwari, G.B.G., 2012. Impact of human activities on ground water forests of Arba Minch: A case study from Ethiopia. International Journal of Basic and Applied Sciences 1, 54-60.

Awulachew, S.B., 2006. Modeling natural conditions and impacts of consumptive water use and sedimentation of Lake Abaya and Lake Chamo, Ethiopia. Lakes \& Reservoirs: Research and Management 11(2), 73-82.

Chanie, S., Tesfaye, D., 2015. Threats of biodiversity conservation and ecotourism activities in Nechsar National Park, Ethiopia. International Journal of Biodiversity and Conservation 7(3), 130-139. 
Chauhan, D., Dhanal, C., Singh, B., Chauhan, S., Todaria, N., Khalid, M., 2008. Regeneration and tree diversity in natural and planted forests in a terai -bhabhar forest in Katarniaghat Wildlife sanctuary, India. Journal of Tropical Ecology 49(1), 53-67.

Dereje, D., 2006. Floristic composition and ecological study of Bibita Forest (Gura Ferda), Southwest Ethiopia, MSc. thesis, Addis Ababa University.

Deribe, G., 2006. "Humbo community-managed natural regeneration project final report," Report, Humbo Regeneration Project, Addis Ababa, Ethiopia.

Dhaulkhandi, M., Dobhal, A., Bhatt, S., Kumar, M., 2008. Community structure and regeneration potential of natural forest site in Gangotri, India. Journal of Basic and Applied Sciences 4(1), 49-52.

Dikaso, U.G., Tesema, T.T., 2016. Floristic composition and diversity of woody plant species of Wotagisho forest, Boloso Sore Woreda, Wolaita Zone, Southwest, Ethiopia. International Journal of Natural Resource Ecology and Management 1(3), 63-70.

FAO, 2007. State of the World's Forests, FAO, Forestry Department.

Fekadu, G., Teshome, S., Ensermu, K., 2012. Structure and regeneration status of Komto Afromontane moist forest, East Wollega Zone, west Ethiopia. Journal of Forestry Research 23(2), 205-216.

Feyera, S., Demel, T., 2001. Regeneration of indigenous woody species under the canopies of tree plantations in Central Ethiopia. Journal of Tropical Ecology 42, 175-185.

Getachew, T., Tamrat, B., Sebsebe, D., 2008. Dryland woody vegetation along an altitudinal gradient on the eastern escarpment of Welo, Ethiopia. Ethiopian Journal of Science and Technology 31, 43-54.

Getaneh, B., 2006. Floristic composition and structure in Beschillo and Abay (Blue Nile) Riverine vegetation. M.Sc. Thesis. AAU, Ethiopia.

Lamprecht, H., 1989. Sericulture in the tropics. Tropical forest ecosystems and their tree species possibilities and methods are the long-term utilization. T2-verlagsgeslls chaft, RoBdort, Germany, 296.

Lemenih, M., Teketay, D., 2006. Changes in soil seed bank composition and density following deforestation and subsequent cultivation of a tropical dry afromontane forest in Ethiopia. Journal of Tropical Ecology 47(1), 1-12.

Maechler, M., Rousseeuw, P., Struyf, A., Hubert, M., Hornik, K., 2015. cluster: Cluster analysis basics and extensions. $R$ package version 3.2 ed.

Markos, K., Simon, S., 2015. Floristic composition, vegetation structure, and regeneration status of woody plant species of oda forest of humbo carbon project, Wolaita,
Ethiopia. Journal of Botany 1, 1-9.

Mekbib, F., 2012. Floristic composition and diversity analysis of vegetation of awash melka kunture prehistoric archaeological site, Ethiopia. MSc. Thesis. AAU, Ethiopia.

Negusse, T., 2006. Ecology and plant use diversity in sof umar area of bale, Southeastern Ethiopia. M.Sc. Thesis. AAU, Ethiopia.

NNP Annual Report, 2010. NNP natural resource for tourism potential and problems associated with it and measures taken to alleviate the problems for the last 14 years October, 2008, Arba Minch. (Amharic version, unpublished report).

Nune, S., Alemu, M., Bluffstone, R., 2007. Policies to increase forest cover in Ethiopia. Proceedings of a Policy Workshop organized by Environmental Economics Policy Forum for Ethiopia (EEPFE). Global Hotel, Addis Ababa, Ethiopia 18-19 September, 2007. Proceedings of the $3^{\text {rd }}$ International symposium on the Flora of Ethiopia and Eritrea at the Crlsberg Academy, Copenhagen.

Oksanen, J., Blanchet, F.G., Kindt, R., Legendre, P., Minchin, P.R., O’Hara, R.B., Simpson, G.L., Solymos, P., Henry, M., Stevens, H., Wagner, H., 2016: Vegan: Community Ecology Package, available at: http://CRAN.R-project. org/package=vegan.

Roberts, D.W., 2015. Package "labdsv". Ordination and Multivariate Analysis for Ecology, available at: https:// cran.r-project.org/web/packages/labdsv/labdsv.pdf.

Samson, S., Tamrat, B., Alemayehu, M., 2010. floristic diversity and structure of nech sar national park, Ethiopia. Journal of the Drylands 3(1), 165-180.

Simon, S., Girma, B., 2004. Composition, structure and regeneration status of woody species in Dindin natural forest, Southeast Ethiopia: An Implication for conservation. Ethiop. Journal of Biological. Science 3(1), 31-48.

Tamene, Y., Tesfaye, A., Sebsebe, D., 2011. Survey and documentation of the potential and actual invasive alien plant species and other biological threats to biodiversity in Awash National Park, Ethiopia. Managing biological invasions 2, 3-14.

Tamrat, B., 1994. Studies on remnant Afromontane forest of the Central plateau of Shewa, Ethiopia. Comprehensive summaries of Uppsala Dissertation from the Faculty of science and Technology 23, Uppsala.

Teshome, S., Demel, T., Sebsebe, D., 2004. Ecological study of the vegetation in Gamo Gofa zone, southern Ethiopia. Journal of Tropical Ecology 45, 209-221.

Workneh, A., Mundanthra, B., Afework, B., 2016. Population ecology of the Grant's gazelle in the plains of Nechisar National Park, Ethiopia. Tropical Ecology 57(2), 205-212. 